\title{
Influences of Nitrogen Fertilizer on Biochemical Attributes of Potato (Solanum tuberosum L.) in Relation to Yield Potential
}

\author{
M. A. Islam ${ }^{1 *}$, M. A. Baset Mia ${ }^{2}$ and M. A. A. Faroque ${ }^{3}$ \\ ${ }^{1}$ Regional Agricultural Research Station, Hathazari, Chittagong, Bangladesh \\ ${ }^{2}$ Department of Crop Botany, Bangabandhu Sheikh Mujibur Rahman Agricultural University \\ Gazipur-1706, Bangladesh \\ ${ }^{3}$ Department of Crop Botany, Bangladesh Agricultural University Mymensingh, Bangladesh \\ Corresponding author: E-mail: islam_ma78@yahoo.com
}

Received: 7 May 2007

Accepted: 30 December 2007

\begin{abstract}
An experiment was conducted at the Bangladesh Institute of Nuclear Agriculture (BINA), Mymensingh, Bangladesh to evaluate the influence of fertilizer- $\mathrm{N}$ on biochemical characteristics, nutrient accumulation and yield of potatoes during the period from November 2002 to March 2003. Two varieties, namely Cardinal and Diamant and five levels of N viz. 0, 100, 125, 150 and $175 \mathrm{~kg} \mathrm{ha}^{-1}$ were applied in a factorial randomized complete block design with three replications. The results indicated that the biochemical characteristics, nutrient concentrations, yield components and yield were significantly influenced by the different levels of $\mathrm{N}$. The nitrate reductase activity, chlorophyll content, total free amino acid showed positive linear relationship with different doses of $\mathrm{N}$-fertilizers. The highest tuber weight and nitrogen accumulation were found from the plants which received $150 \mathrm{~kg} \mathrm{~N}$ $\mathrm{ha}^{-1}$. Application of $150 \mathrm{~kg} \mathrm{~N} \mathrm{ha}^{-1}$ resulted in best biochemical characteristics, nutrient uptake, yield and yield components of potato varieties- Cardinal and Diament.
\end{abstract}

Keywords: Potato, N-fertilizers, biochemical characters, yield

\section{Introduction}

Potato (Solanum tuberosum L.) is an important tuber crop and it is the second largest food crop after cereal in Bangladesh (FAO, 2001). It is superior to other crops in respect of calorie, protein and energy production per hectare per day (Horton, 1988). The potato cultivation in Bangladesh has increased considerably in the last decade in terms of area and total production without a commensurate increase in per hectare yield. The average yield is $12.6 \mathrm{t} \mathrm{ha}^{-1}$ in Bangladesh (FAO, 2001). It is quite low in comparison to that of the leading potato growing countries of the world such as the Netherlands (45.56 $\left.\mathrm{t} \mathrm{ha}^{-1}\right)$, UK (40.03 $\left.\mathrm{t} \mathrm{ha}^{-1}\right)$, USA (42.71 t $\mathrm{ha}^{-1}$ ), Japan (30.19) and India (18.64) (FAO, 2001). The main reasons responsible for such a low yield of potato in Bangladesh are nonjudicious application of manure and fertilizers. Among the various ways of vertical increase in production, judicious application of fertilizer is a 
prerequisite as potato is a heavy feeder (Hossain, 1998). Fertilizer-N is one of the essential inputs for crop production. Non-judicious application of fertilizers is considered as one of the main factors for the poor yield of potato in Bangladesh. Potato is considered as a gross feeder and it requires adequate supply of different plant nutrients, particularly nitrogen for optimum growth of plants and high yield of tubers. However, under Bangladesh conditions, use of both under and over doses of $\mathrm{N}$ has been reported (Hussain, 1998). The use of low $\mathrm{N}$ results in reduction in yield of potato. On the other hand, excessive use of $\mathrm{N}$ results in wastage of fertilizer and high cost of production. Excessive application of $\mathrm{N}$-fertilizer resulted in luxuriant vegetative growth despite of tuber formation. It is therefore, necessary to increase the $\mathrm{N}$ use efficiency by identifying the maximum $\mathrm{N}$-assimilation pattern and consequently carbohydrate translocation to the economic sink, which could minimize the assimilatory losses of $\mathrm{N}$-fertilizer. Hence, a study was undertaken to identify nitrogen efficient variety of potato and optimum dose of nitrogen through above mentioned biochemical and physiological parameters especially on the basis of NR activity scale for $\mathrm{N}$-assimilation pattern through nitrate reductase enzyme activity and biochemical attributes to determine optimum $\mathrm{N}$ level for maximum yield.

\section{Materials and Methods}

The experiment was conducted at the Bangladesh Institute of Nuclear Agriculture (BINA), Mymensingh, Bangladesh during the period from November 2002 to March 2003. The experimental area enjoys a sub-tropical climate, which is characterized by high temperature, high humidity, heavy precipitation during April to October, and relatively low temperature and low rainfall during November to March. The crop used in this study was potato (Solanum tuberosum L.) varieties Cardinal and Diamant. The seeds were collected from the Bangladesh Agricultural Development Corporation (BADC), Mymensingh, Bangladesh. The design of the experiment was factorial randomized complete block with three replicates. Five levels of Nfertilizers namely $0,100,125,150$ and $175 \mathrm{~kg} \mathrm{~N}$ $\mathrm{ha}^{-1}$ were applied in this experiment. Triple super phosphate (TSP), muriate of potash (MOP), and gypsum at 150,120 and $10 \mathrm{~kg} \mathrm{ha}^{-1}$ respectively were mixed into the soil as basal dose during land preparation according to fertilizer recommended guide (BARC, 1997). Data on biochemical parameters e.g. nitrate reductase and chlorophyll content were taken followed Stewart and Orebamjo (1979) and Arnon (1949) methods, respectively. Soluble protein was determined accordingly to Lowry et al. (1951). Total free amino acid and sugar was determined as Ninhydrin method and the methodology according to Karmoker (1981), respectively. Total $\mathrm{N}$ content of different plant parts was estimated following micro Kjeldahl method .

The collected data were statistically analyzed to find out the level of significance using MSTATC package programme developed by Russel (1986). The mean differences were compared by Duncan's New Multiple Range Test (DMRT) and regression at $5 \%$ level of significance (Gomez and Gomez, 1984).

\section{Results and Discussion}

\subsection{Nitrate reductase activity (NRA)}

The effect of different $\mathrm{N}$ levels significant on NRA throughout the growth period (Fig. 1A). It was observed that the maximum NRA was at 38 DAP irrespective of different $\mathrm{N}$ levels and thereafter, it was gradually decreased up to 59 DAP. The NRA showed highly significant positive correlations $\quad\left(\mathrm{r}=0.966^{* *}, \mathrm{r}=0.988^{* *}\right.$, and $\mathrm{r}=0.99^{* *}$ ) with $\mathrm{N}$ levels in leaves at 38,45 and 52 DAP, respectively (Fig. 2). However, at 59 DAP correlation between NRA and N levels was not significant $(r=0.706)$. Both the varieties possessed similar NR activity pattern with the plant age i.e. both varieties showed gradual declining activity of NR with the advancement of plant age (Fig. 1B). Nitrate reductase catalyzes the reduction of nitrate to nitrite, which is considered rate-limiting in nitrate assimilation in plants and nitrate assimilating organisms (Bevers and Hageman, 1969; Solomonson and Barder, 1990). 

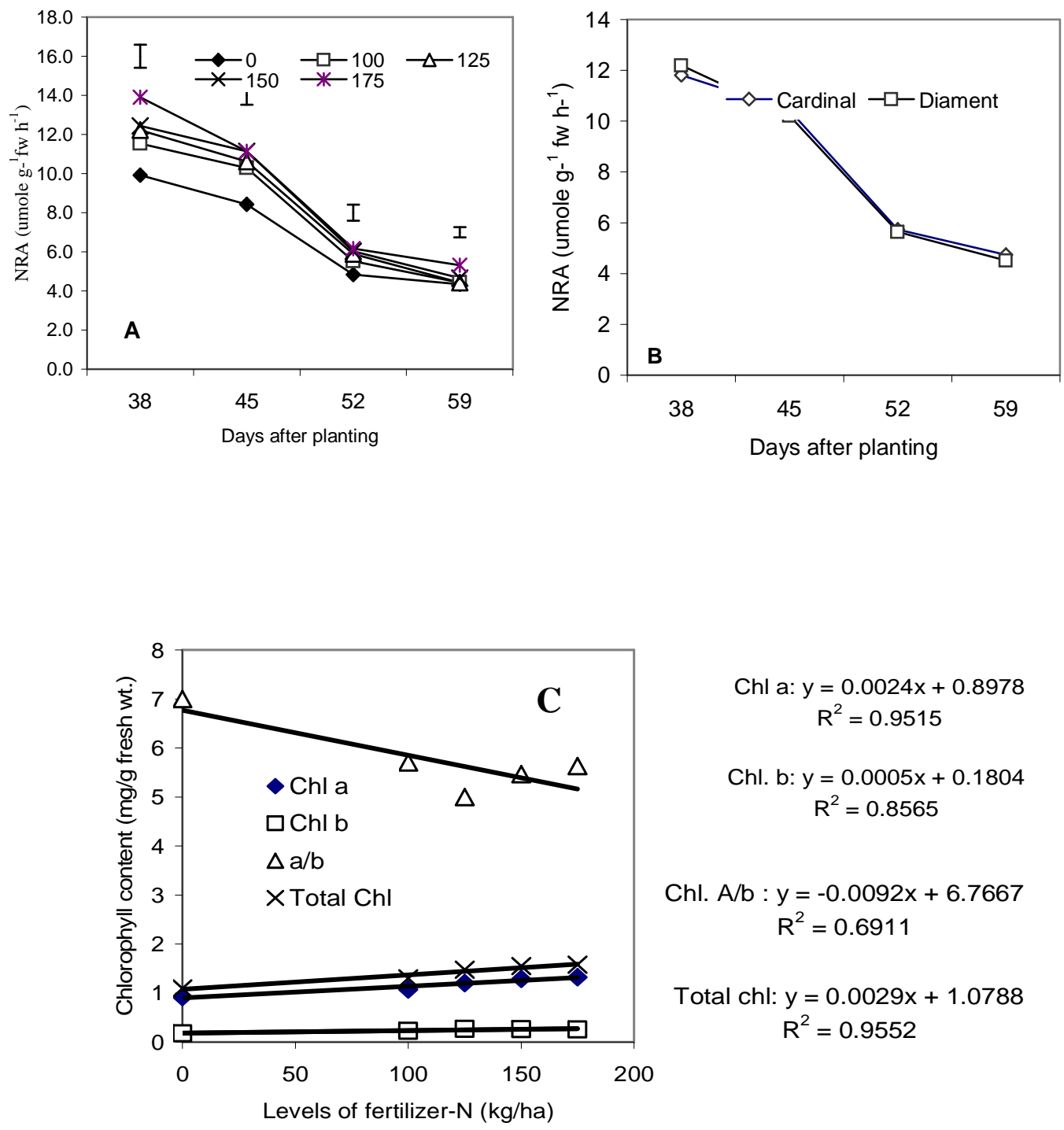

Chl a: $y=0.0024 x+0.8978$

$$
R^{2}=0.9515
$$

Chl. b: $y=0.0005 x+0.1804$

$$
\mathrm{R}^{2}=0.8565
$$

Chl. $A / b: y=-0.0092 x+6.7667$

$R^{2}=0.6911$

Total chl: $y=0.0029 x+1.0788$

$\mathrm{R}^{2}=0.9552$

Fig.1. A-Effect of different levels of fertilizer-N on nitrate reductage activity at different days after transplanting, B-Varietal effect on the NRA under different levels of N, C- The effect of different levels of fertilizer-N on chlorophyll a, chlorophyll b, chlorophyll $\mathrm{a} / \mathrm{b}$ ratio and total chlorophyll content of potato 

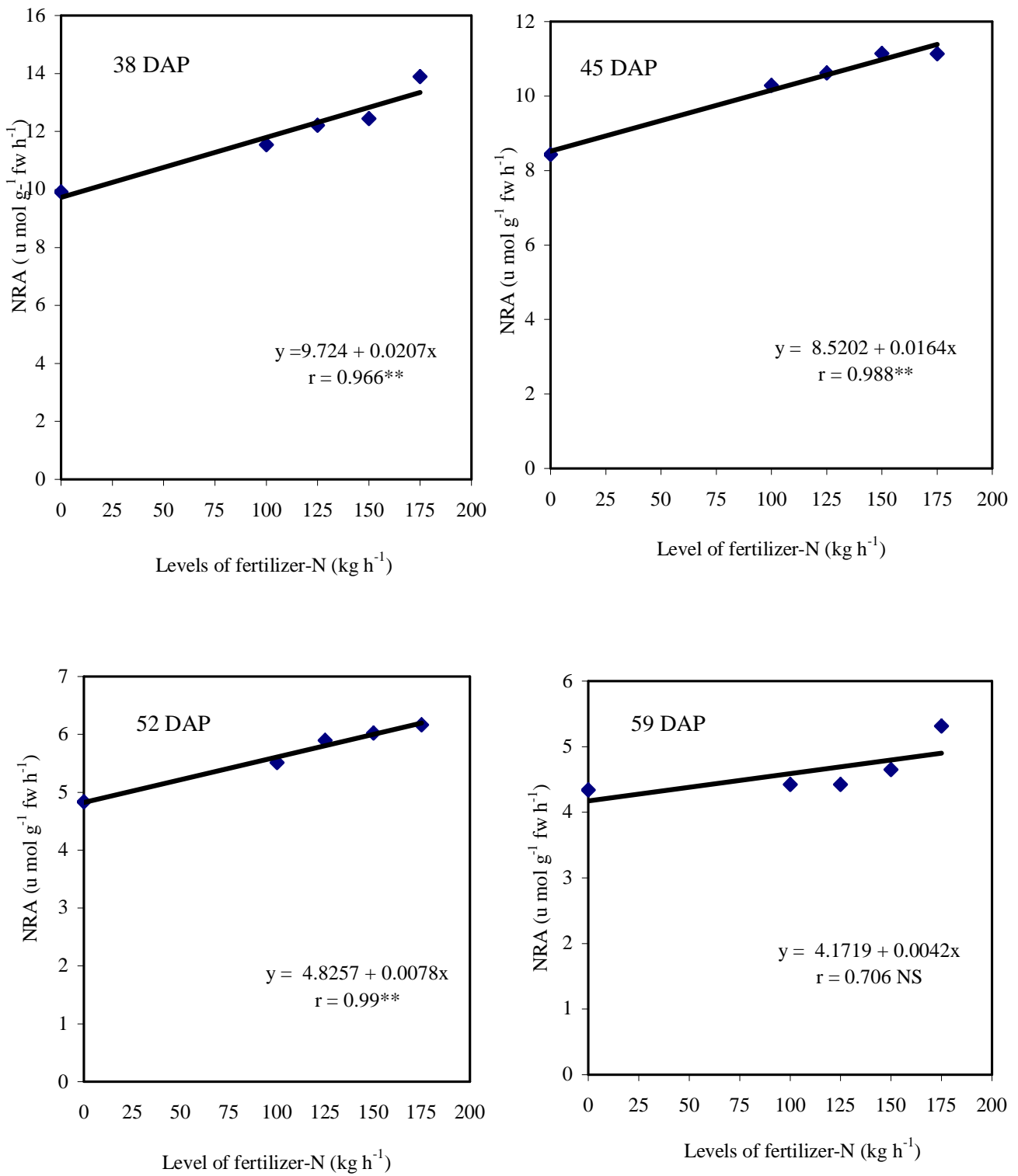

Fig. 2. Effect of different levels of frtilizer-N on NRA at $38,45,52$ and 60 DAP 
The NRA in plants is regulated by nitrate, light, growth hormones, reduced nitrogen metabolites, and phosphorylation (Crawford, 1995). Experimental result showed that the NR activity was increased with increasing nitrogen levels. This pattern may be attributed to nitrate availability in the soil. nitrate availability in the soil would influence NRA. This was expected because NR is a substrate inducible enzyme. The leaf NR activity was maximum in the initial growth stage and declined subsequently with age. The reduction and assimilation of nitrate occurs in above or below ground organ and it depends on the relative levels of nitrate reductase in different plant parts. Nitrate reductase activity is often positively correlated with the total protein and nitrogen contents and some time also with the overall productivity of the plants. Nirate reductase activity was maximum in the leaves of 45 days old plants in both the cultivars and declined towards maturity (Fig. 1A). At 100 days, the activity was only about $10-50 \%$ of the original activity present at 45 days (Fig. 1A). The decline in NRA with age is reported in many plants including potato. The fall in activity may be related to a general protein breakdown and to the reduction in the protein synthesizing capacity of the plant. The flow of $\mathrm{N}$ from leaves to tubers could be one of the reasons for the decline in NR activity with age. Davies et al. (1987) observed that decline in NR activity was accompanied by remobilization of reduced $\mathrm{N}$ from leaves in potato. The NR activity was high in high levels of $\mathrm{N}$ indicating greater assimilation of $\mathrm{N}$. The positive linear correlation of nitrogen levels and NRA may be due to increase protein synthesizing capacity of plant. The highest NRA was observed at 38 DAP and it declined gradually at 45, 52 and 59 DAP. At 59 DAP the levels of fertilizer-N and NRA had no significant correlation. Which might be indicated that the optimum fertilization time before 59 DAPS.

\subsection{Chlorophyll content}

Chlorophyll-a content showed a positive linear correlation with N levels (Fig. 1C). Similarly, a positive linear correlation was observed in chlorophyll-b content (Fig. 1C). A negative linear correlation shown between chlorophyll $\mathrm{a} / \mathrm{b}$ ratio and $\mathrm{N}$ levels (Fig. 1C). The effect of $\mathrm{N}$ on total chlorophyll accumulation was significant which, was increased linearly with increasing of N-fertilizer (Fig. 1C). Total chlorophyll, chlorophyll-a and chlorophyll-b accumulation increased significantly with increasing levels of nitrogen. There was a linear relationship between chlorophyll and levels of fertilizer-N, and the relationship is highly significant. Synthesis of chlorophyll is the effect of higher protein content. Protein especially, soluble protein content was increased due to increased level of fertilizer-N as discussed above. This result was supported by Millard et al. (1990), Vyas et al. (1995), Mishra et al. (1994) and Kumar and Bandara (2001), who found that potato leaves chlorophyll concentration was increases with increasing fertilizer $\mathrm{N}$ application. Leaf chlorophyll contents positively influenced by increased $\mathrm{N}$ fertilizer application and the levels of nitrogen under water-stressed condition caused by $49 \%$ reduction in the leaf values of leaf chlorophyll. Application of $\mathrm{N}$-fertilizer increased both chlorophyll-a and chlorophyll-b in mustard. Lack of $\mathrm{N}$ application caused $10 \%$ reduction of leaf chlorophyll content from that of high $\mathrm{N}$ treatment plants at their peak. Thus, the enhancement of chlorophyll in plants is of great significance from production viewpoint. Nitrogen being the constituent of chlorophyll and because promotes cell elongation, functional life of plants and production of carbohydrates. The results were also supported by Li et al. (1985) who found that photosynthetic rate was positively correlated with NR activity. At 45 DAP, the total chlorophyll, chlorophyll-a and chlorophyll-b contents were higher than those at 60 DAP. The greenness of plants also decreased with increasing plant age which might be due to decreased $\mathrm{N}$ concentration in soil by consuming plant and decreased cell activity by which decreased light harvested efficiency at mature stage. Increase in total chlorophyll, chlorophyll-a and chlorophyll-b due to increased $\mathrm{N}$ levels might be associated with soluble protein, total free amino acid, total sugar. Leaf chlorophyll is higher at 45 DAP than 60 DAP might be that 
causes of plant receiving more fertilizer-N.The chlorophyll-a is nearly always present is an amount three times as high as that chlorophyll-b. The ratio of chlorophyll $\mathrm{a} / \mathrm{b}$ was higher at early stage than later stage, which might be at later stage chlorophyll a decrease was higher than chlorophyll-b. That reason is that, in later stage light-harvesting capacity of plant might be decreased due to aging and senescence of other leaves. On the other hand we assumed that chlorophyll decreased with increasing age due to remobilization of nutrient of leaves in developing tuber.

\subsection{Total free amino acid}

Total free amino acid accumulation had positive relation with nitrogen levels, which indicated that total free amino acid increased gradually with the increased of nitrogen levels (Fig.3A). Total free amino acid content showed a highly (1\%) significant relation $\left(\mathrm{r}=0.947^{* *}\right)$ with nitrogen levels. Varietal effect on total free amino acid content had no significant difference among the varieties at 45 and 60 DAP (Fig. 3B). Total free amino acid is a basic constituent of protein. Amino acid content significantly influenced due to the application of $\mathrm{N}$-fertilizer. Amino acid increased linearly with the level of fertilizer-N. Higher N-fertilizer accelerated the N uptake and $\mathrm{N}$ assimilation as evidenced by higher NRA. The results of the present experiment supported by Peshin and Singh (1999), who concluded that higher $\mathrm{N}$ rates increased total free amino acid in leaves. This was might be due to probable incorporation of its nitrogen into amino acids.

\subsection{Soluble Protein}

Soluble protein showed highly significant positive correlation with $\mathrm{N}$ levels in leaves of potatoes (Fig. 3C). This indicated that increasing leaf $\mathrm{N}$ content increased the soluble protein content. Varietal effect on soluble protein content had no significant difference among the varieties (Fig. 3D). Soluble protein content increased with the increment of fertilizer-N.
There was a positive correlation and the relationship was significant. The higher soluble protein is the results of higher amino acid. Similarly, Amin et al. (2002) reported that the total amount of soluble protein increase with increasing leaf $\mathrm{N}$ content. Similar results were described by Davies et al. (1987); Marwaha (1997); Vyas et al. (1995), Peshin and Singh (1999), who reported that leaf protein content increased with increasing $\mathrm{N}$-supply. Soluble protein content of the leaves decreased with the maturity, indicating the translocation of leaf nitrogen to the sink. The $\mathrm{N}$ uptake was substantially increased by fertilizer application. At high $\mathrm{N}$ rate the crops took up more than needed to satisfy their immediate requirements for growth. Initially, this extra $\mathrm{N}$ appeared predominantly in the from of soluble protein in the leaves. It might be due to that $\mathrm{N}$ is the main constituent of amino acid and amino acid is a basic component of protein synthesis.

\subsection{Total sugar}

Results revealed that total sugar accumulation in leaves increased linearly with $\mathrm{N}$-fertilizer, although it was not significant (Fig. 4A). There was no significant varietal difference on total sugar content in leaves of potatoes (Fig. 4B).

Total sugar is the basic food reserves and the main structural materials of plants. Total sugar accumulation in leaves and tuber positively influenced due to $\mathrm{N}$ application. Total sugar linearly increased with the rate of $\mathrm{N}$-fertilizer. The higher sugar content was due to higher photosynthetic rate, which is enhanced due to enzymatic activity. Results of this experiment reflected that $\mathrm{N}$-treated plants showed higher NRA compared to control. In addition, this might be due to promote the production of carbohydrate by chlorophylls and increasing $\mathrm{N}$ levels increases chlorophyll contents in leaves. This results supported by Peshin and Singh (1999) and Mack et al. (2002) who found that tuber sucrose and starch increased by $40 \%$, whereas glucose and fructose declined two-fold as plant $\mathrm{N}$ status increased. 

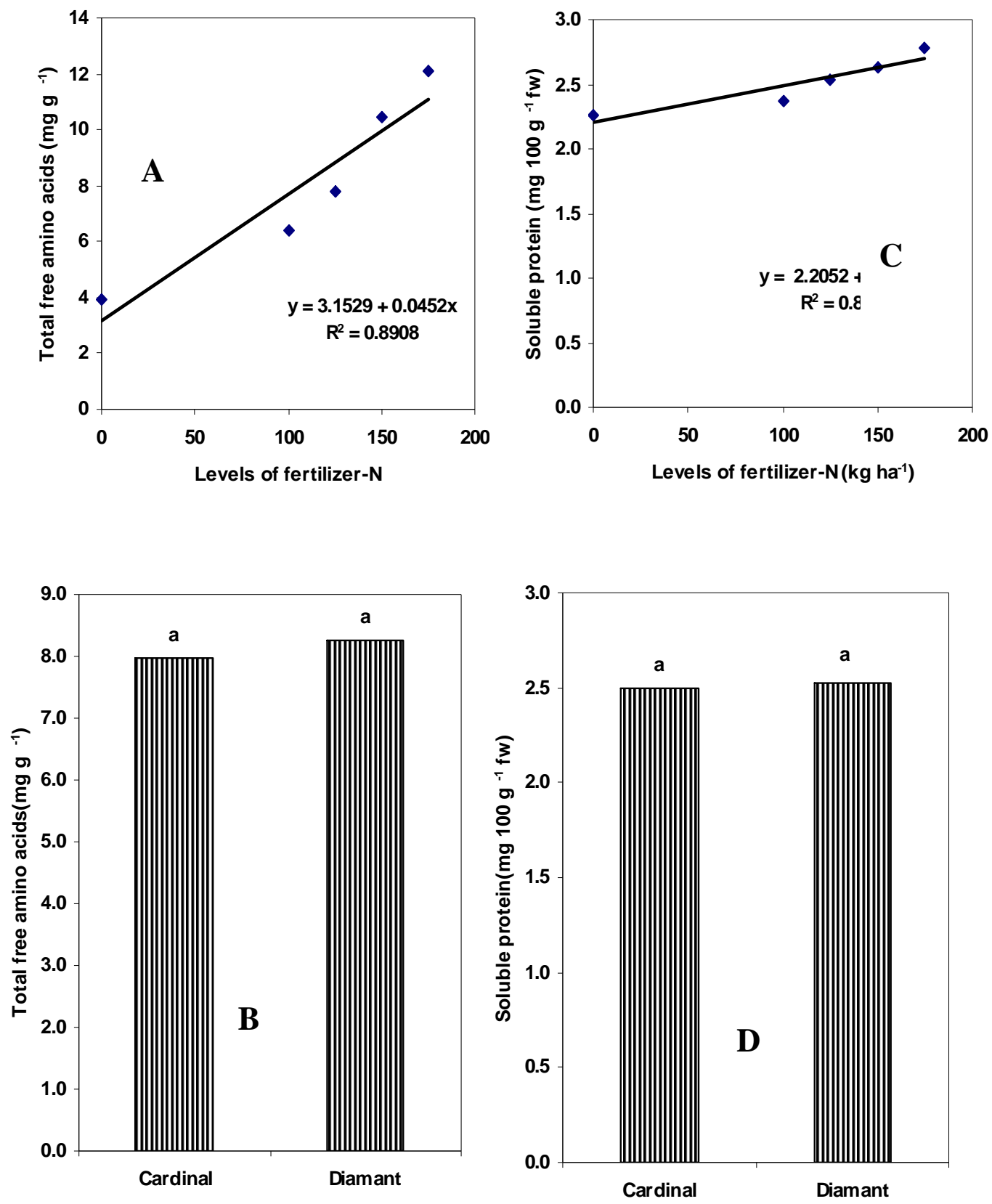

Fig.3. Effect of different levels of fertilizer-N on A: total free amino acids content, B: varietal effects on total free amino acid content, C: soluble protein content and D: varietal effects on soluble content 

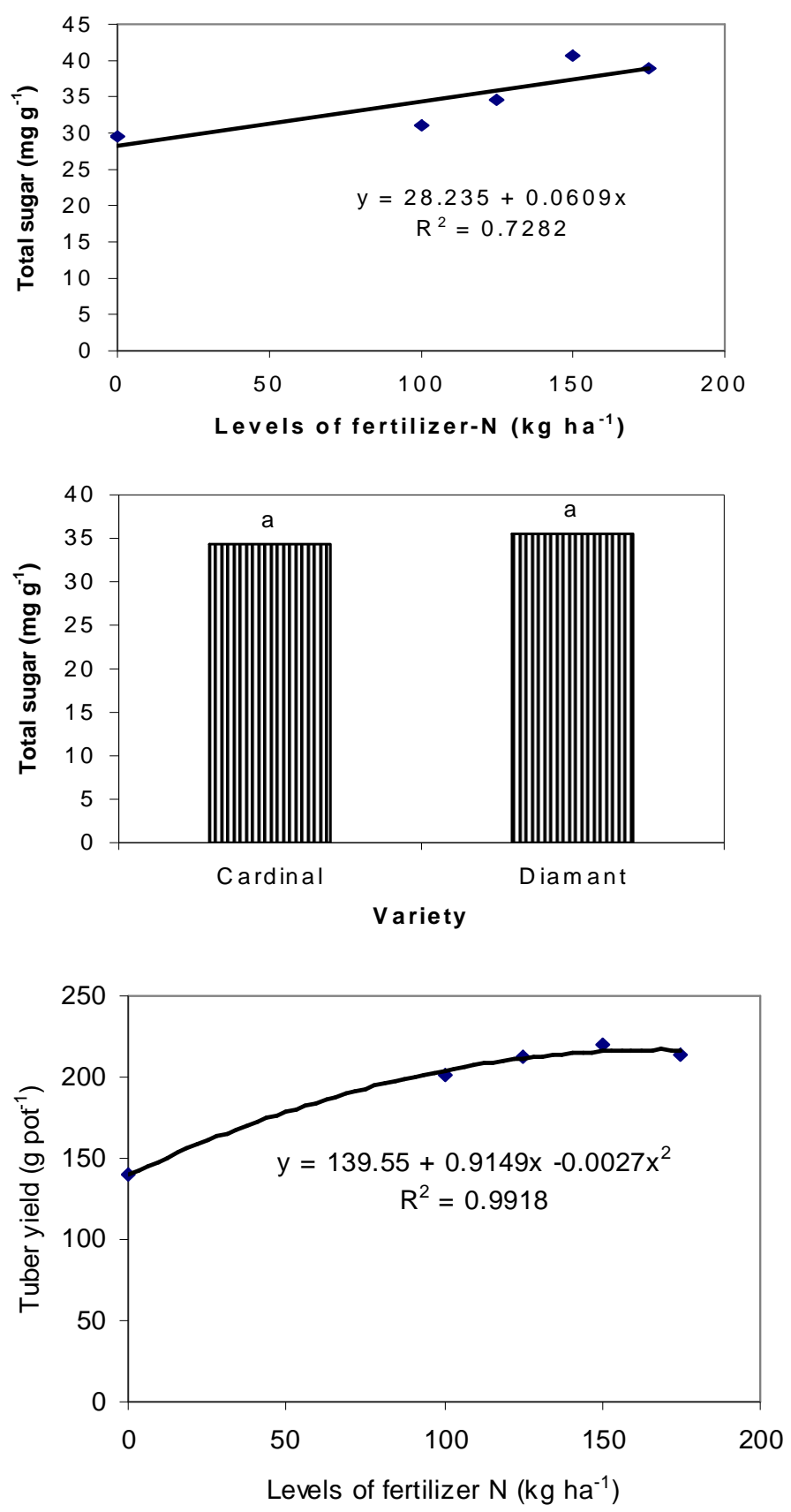
Table 1. Effect of different levels of fertilizer-N $\left(\mathrm{kg} \mathrm{ha}^{-1}\right)$ on $\mathrm{N}$ concentration, $\mathrm{N}$ accumulation, crude protein content and yield in potatoes

\begin{tabular}{ccccc}
\hline $\begin{array}{c}\text { Levels of fertilizer-N (kg } \\
\left.\mathrm{h}^{-1}\right)\end{array}$ & $\begin{array}{c}\text { Concentration } \\
\text { of } \mathrm{N}(\%)\end{array}$ & $\begin{array}{c}\text { Total N } \\
\text { accumulation }(\mathrm{g})\end{array}$ & $\begin{array}{c}\text { Crude protein } \\
(\%)\end{array}$ & $\begin{array}{c}\text { Tuber fresh } \\
\text { wt. }\left(\mathrm{g} \mathrm{pot}^{-}\right.\end{array}$ \\
\hline 0 & $1.51 \mathrm{~d}$ & $0.58 \mathrm{c}$ & $0.48 \mathrm{c}$ & $139.93 \mathrm{~b}$ \\
100 & $1.78 \mathrm{c}$ & $0.76 \mathrm{~b}$ & $0.64 \mathrm{~b}$ & $200.96 \mathrm{a}$ \\
125 & $2.08 \mathrm{a}$ & $0.97 \mathrm{a}$ & $0.83 \mathrm{a}$ & $212.75 \mathrm{a}$ \\
150 & $1.96 \mathrm{~b}$ & $0.99 \mathrm{a}$ & $0.83 \mathrm{a}$ & $220.13 \mathrm{a}$ \\
175 & $1.93 \mathrm{~b}$ & $0.95 \mathrm{a}$ & $0.79 \mathrm{a}$ & $214.18 \mathrm{a}$ \\
\hline Level of significance & $* *$ & $* *$ & $* *$ & $* *$ \\
\hline
\end{tabular}

In a column, means having same letter (s) do not differ significantly at 5\% level of significance by DMRT

Table 2. Varietal effect on $\mathrm{N}$ concentration, $\mathrm{N}$ accumulation, crude protein content and yield in potatoes

\begin{tabular}{lcccc}
\hline Variety & $\begin{array}{c}\text { Concentration of } \mathrm{N} \\
(\%)\end{array}$ & $\begin{array}{c}\text { Total } \mathrm{N} \\
\text { accumulation } \\
\left(\mathrm{g} \mathrm{pot}^{-1}\right)\end{array}$ & $\begin{array}{c}\text { Crude } \\
\text { protein } \\
(\%)\end{array}$ & $\begin{array}{c}\text { Tuber fresh wt. } \\
\left(\mathrm{g} \mathrm{pot}^{-1}\right)\end{array}$ \\
\hline Cardinal $\left(\mathrm{V}_{1}\right)$ & 1.83 & 0.83 & 0.69 & 197.75 \\
Diamant $\left(\mathrm{V}_{2}\right)$ & 1.87 & 0.87 & 0.73 & 197.40 \\
Level of & $\mathrm{NS}$ & $\mathrm{NS}$ & $\mathrm{NS}$ & $\mathrm{NS}$
\end{tabular}

significance

\subsection{Nitrogen accumulation}

The effect of different levels of fertilizer- $\mathrm{N}$ on $\mathrm{N}$ concentration and total $\mathrm{N}$ accumulation in plants was highly significant (Table 1). The highest $\mathrm{N}$ concentration was found from the plants, which was treated with $125 \mathrm{~kg} \mathrm{~N} \mathrm{ha}^{-1}$ and the lowest from the control. Similarly, the highest total N accumulation was observed from $150 \mathrm{~kg} \mathrm{~N} \mathrm{ha}^{-1}$, which was statistically similar at 125 and $175 \mathrm{~kg}$ $\mathrm{N} \mathrm{ha}{ }^{-1}$, and the lowest total nitrogen accumulation was observed from control $(0 \mathrm{~kg} \mathrm{~N}$ $\left.\mathrm{ha}^{-1}\right)$. The effect of varieties on total nitrogen accumulation in plants was not significant (Table 2). Nitrogen accumulation in tuber, root, shoot and total $\mathrm{N}$ accumulation was significant with $\mathrm{N}$ levels. The $\mathrm{N}$ uptake by potato had positive and significant relation with the tuber yield. This agrees with the findings of Sharma and Grewal (1987). The highest $\mathrm{N}$ accumulation in tuber, root, shoot and total $\mathrm{N}$ accumulation was found from the treatment $150 \mathrm{~kg} \mathrm{~N} \mathrm{ha}^{-1}$. Which was the similar treatment that produced highest yield. So, it will be said that there might be a relationship between $\mathrm{N}$ accumulation in tuber, root and shoot with tuber yield. Freash tuber yield was obtained from the treatment of $150 \mathrm{~kg} \mathrm{~N} \mathrm{ha}{ }^{-1}$. Which is confirming by Kushwah (1989); Sarker et al. (1996); Saini and Singh (1988), who suggested that fresh tuber yield were increased with increased in $\mathrm{N}$ rate up to $150 \mathrm{~kg} \mathrm{ha}^{-1}$. Tuber diameter and weight per plant were highest at 25 $\mathrm{cm}$ spacing and application of $148 \mathrm{~kg} \mathrm{~N} \mathrm{ha}^{-1}$. Similarly Chaurasia and Singh (1995) found that the net returns were highest with the application of $150 \mathrm{~kg} \mathrm{~N}$, which was more economic than other treatment. It may be said that the crop got favorable environment to synthesis more assimilates and to translocate that for sink 
formation. Both excess and under doses of nitrogen reduced its yield. A curvilinear relationship was found. That might be due to luxury consumption. Up to a certain limit yield was not increased with increasing $\mathrm{N}$ levels.

\subsection{Crude protein content in tuber}

The highest crude protein content was recoded in the plants when it was applied $150 \mathrm{~kg}$ $\mathrm{N} \mathrm{ha}^{-1}$, which was similar to 125 and $175 \mathrm{~kg} \mathrm{~N}$ $\mathrm{ha}^{-1}$ and the lowest was observed at control (Table 1). There were no significant differences in crude protein content between the varieties. Nitrogen and protein content in different organ was increased successively and significantly with increasing $\mathrm{N}$ levels. It might be due to the accumulation of $\mathrm{N}$ resulting in higher protein content. The tuber yield had highly significant correlations with $\mathrm{N}$ concentration in leaves. In shoot, the highest $\% \mathrm{~N}$ was found from $150 \mathrm{~kg} \mathrm{~N}$ $\mathrm{ha}^{-1}$ and the tuber yield was highest at same treatment. This result is in agreement with those obtained by Sharma and Grewal (1987), who found that yield increased by increasing the $\mathrm{N}$ rates and were decreased with further increase in $\mathrm{N}$ rates. $\mathrm{N}$ accumulation declined in response to the lowest application of nitrogen, shoot growth was limited prior to, and to a greater extent than, the photosynthetic rate.

\subsection{Tuber fresh weight}

The effect of different levels of fertilizer-N on tuber freash weight was significant at $1 \%$ levels. The highest tuber fresh yield was recorded by the application of $150 \mathrm{~kg} \mathrm{~N} \mathrm{ha}{ }^{-1}$, which was statistically identical with 100, 125 and $175 \mathrm{~kg} \mathrm{~N}$ $\mathrm{ha}^{-1}$ the lowest was obtained from control. Tuber fresh yield in different nitrogen applied plants was significantly higher compared to control (Table 1). The tuber fresh yield showed curvilinear relation $\left(\mathrm{R}^{2}=0.99 * *\right)$ with fertilizer$\mathrm{N}$ (Fig.4C). The influence of varieties on the fresh tuber yield was not significant (Table 2).

\section{Conclusions}

The results indicated that application of fertilizer-N increased biochemical parameters namely NRA, soluble protein, chlorophyll content, amino acid, total sugar; nutrient content and yield. Application of $150 \mathrm{~kg} \mathrm{~N} \mathrm{ha}^{-1}$ showed the best performance of maximum parameter and yield. Thus, application of $150 \mathrm{~kg} \mathrm{~N} \mathrm{ha}^{-1}$ might be a recommended dose for maximum tuber yield of potato varieties, Cardinal and Diamant.

\section{References}

Amin, S. M. N., Uchida, N., Masumoto, C., Hatanak, T. and Tsugavwa, H. 2002. Partitioning of absorbed $\mathrm{N}$ to Chloplast, Soluble protein and Rubisco in rice leaves under low nitrogen supply. Environment Control Biology, 40(2) 201-206.

Arnon, D.I. 1949. Copper enzymes in isolated Chloroplasts, Polyphenol Oxidaze in Beta vulgaris. Plant Physiology, 24: 1-5.

Bevers, L. and Hageman, R. H. 1969. Nitrate reduction in higher plants. Annual Review of Plant Physiology, 20: 495-552.

Chaurasia, S. N. S. and Singh, K. P. 1995. Tuber yield and uptake of $\mathrm{N}, \mathrm{P}$ and $\mathrm{K}$ in the leaves, stems and tubers as affected by nitrogen levels and haulms cutting in potato cv. Kufri Bahar. Journal of Indian Potato Association, 22(1/2): 80-82.

Crawford, N. M. 1995. Nitrate nutrient and signal for plant growth. Plant and Cell 7: 859-868.

Davies, H.V. and Ross, H. A. 1987. Nitrate assimilation in the potato crop. Journal of the Science of Food and Agriculture. 38(4): 319-320.

FAO, 2001. Production Yearbook. Food and Agriculture Organization of the United Nations, Rome. pp. 83-84.

Gomez, K. A. and Gomez, A. A.1984. Statistical Procedures for Agriculture Research. $\left(2{ }^{\text {nd }} E D\right)$. John Wiley and Sons, New York. p. 640.

Horton, D. E. 1988. Potatoes Truly a World Crop, SPAN. 30(3): 116-118. 
Hussain, M. M. 1998. Report on Seed Potato Production Technology by ACF Borrowers, Agro-based Industries and Technology Development Project. Banani, Dhaka, 60 p.

Karmoker, J. L.1981. Ph. D. Thesis Submitted to the School of Agric. La Trobe Univ. Australia.

Kumara, A. D. S. and Bandara, D. C. 2001. Influence of nitrogen application and varietal differences on selected physiological parameters of sugarcane. Tropical Agricultural Research, 13: 220230.

Kushwah, V. S. 1989. Effect of different levels of $\mathrm{N}$ and planting density on productivity of seed potato (Solanum tuberosum L.). Indian Journal of Agricultural Sciences, 59(9): 561-565.

Li, H. Z., Lian, Z. D., Lu, G. Y. LI, M. X. and Piao , S. J. 1985. Studies on nitrate reductase activity and nitrogen response in rice plants. VII. The relationship between NR activity of rice leaves and the level of $\mathrm{N}$ applied. Plant Physiology Communications, 5: 14-16.

Lowery, O.H., Roserrough, N. J., Farr, A. L. and Randall, R. J. 1951. Protein measurement with the folin phenol reagent. Journal of Biological Chemistry, 193: 265-275.

Mack, G. and Schjoerring, J. K. 2002. Effect of $\mathrm{NO}_{3}^{-}$Supply on $\mathrm{N}$ metabolism of potato plant (S. tuberosum) with special focus on the tubers. Plant, Cell Environment, 25(8): 999-1009.

Marwaha, R. S. 1998. Nitrate assimilation in potato cultivars during plant growth. Indian J. Plant Physiology, 3(2): 147151.

Millard, P., Wright, G. G., Adams, M. J. Birnie, R. V. and Whitworth, P. 1990. Estimation of light interception and biomass of the potato (Solanum tuberosum L.) from reflection in the red and near infrared spectral bands. Agricultural and Forest Meteorology, 53(1-2): 19-31.

Mishra, S., Bhutani, S. and Singh B. D. 1994. Influence in Brassica juncea during early seedling growth. Indian Journal of Plant physiology, 37 (i). 12-16.

Peshin, A. and Singh, B. 1999. Biochemical composition of potato tubers as influenced by higher nitrogen application. Journal of Indian Potato Association, 26(3-4): 145-147.

Russel, D. F. 1986 MSTAT-C package programme. Crop and Soil Science Department, Michigan State University, U.S.A.

Saini, S. S. and Singh, J. P. 1988. Development of agronomic practices for seed potato production. Annual Scientific Report, CPRI, Shimla. pp. 165-166.

Sarker, N. I., Zaman, S., Islam, M. S. and Mannaf, M. A. 1996. Effect of fertilizers alone and in combination with cow dung on the growth and yield of pototo. Bangladesh Journal of Agricultural Sciences, 21(1): 275-282.

Sharma, U. C. and Grewal, J. S. 1987. Effect of sources, levels and methods of nitrogen application on the yield and nitrogen uptake of potato. Indian Journal of Agricultural Sciences, 57(9): 640-645.

Solomonson, L. P. and Barber, M. G. 1990. Assimilatory nitrate reductase: functional properties and regulation. Annual Review of Plant Physiology, 41: 225-253.

Stewart, G. R. and T. O. Orebamjo. 1979. Some unusual characteristics of nitrated reducation in Erythrana senegalensis D.C., New Phytologist, 83: 311-319.

Vyas, S. P., Garg, B. K., Kathju, S., Lahiri, A. N. 1995. Influence of nitrogen on Indian mustard grown under different levels of stored soil moisture. Journal of Arid Environments, $\quad$ 29(2): $\quad$ 173-184 
